\title{
Vitamin D Supplementation: A Potential Approach for Coronavirus/COVID-19 Therapeutics?
}

\author{
John F. Arboleda ${ }^{1,2 \star}$ and Silvio Urcuqui-Inchima ${ }^{1}$ \\ ${ }^{1}$ Group of Immunovirology, Faculty of Medicine, University of Antioquia, Medellin, Colombia, ${ }^{2}$ Behavioural Science and \\ Health Care Habits Unit, Comfama, Medellin, Colombia
}

Keywords: SARS-Cov-2, COVID-19, vitamin D, antiviral, anti-inflammatory

The ongoing pandemic: Coronavirus disease 2019 (COVID-19) caused by SARS-CoV-2 has become one of the most important epidemiological events within the last 100 years, causing devastating consequences for the public health systems and the socioeconomical tissue around the world (1-3). Infection with SARS-CoV-2 can lead to a mild or highly acute respiratory syndrome fueled by altered secretion of inflammatory cytokines (cytokine storm) that can be fatal within children, elderly populations, patients with chronic pulmonary or hypertension diseases, and people living in cities with poor air quality $(3,4)$. While viral spreading and severity indexes are growing as the virus reaches new geographic areas, clinical trials for several vaccine prospects are being performed with the caveat that it may take more than 6 months to provide data of their efficiency and sero-protection levels $(2,5-7)$. Consequently, the remaining alternatives to counteract COVID-19 disease and pandemics are currently based on (i) the implementation of

OPEN ACCESS

Edited by:

Susu M. Zughaier,

Qatar University, Qatar

Reviewed by:

William B. Grant,

Sunlight Nutrition and Health Research Center, United States

*Correspondence: John F. Arboleda guanojf@gmail.com

Specialty section: This article was submitted to

Viral Immunology,

a section of the journal

Frontiers in Immunology

Received: 31 March 2020

Accepted: 09 June 2020

Published: 23 June 2020

Citation:

Arboleda JF and Urcuqui-Inchima S (2020) Vitamin D Supplementation: A

Potential Approach for

Coronavirus/COVID-19 Therapeutics?

Front. Immunol. 11:1523.

doi: 10.3389/fimmu.2020.01523 a broad-spectrum of antivirals that could attenuate the virus infection, (ii) clinical relief of acute inflammatory symptoms, and (iii) social isolation of at risk populations to avoid propagation $(5,8)$. However, given the uncertainty for specific treatment and the economic consequences of social isolation, especially in developing countries, repurposing of current drugs it is imperative to develop quick, and cost-effective therapeutic strategies to protect vulnerable populations (9).

A potential alternative is vitamin $\mathrm{D}$, a natural immunoregulator that has been demonstrated to enhance antimicrobial activity against several pathogens including respiratory viruses (10, 11). Indeed, both in vitro observations and supplementation trials have extensively shown the restrictive features of vitamin $\mathrm{D}$ against respiratory viruses including: syncytial virus, influenza, and coronaviruses $(8,10-19)$ and other non-respiratory viruses, such as human immunodeficiency virus 1, hepatitis c virus, and dengue virus (20-22). Classically, the mechanisms reported to support these antiviral effects are based on the ability of vitamin $\mathrm{D}$ to upregulate antimicrobial peptides and induce antiviral cytokines to interfere the viral replicative cycle (10, 12, 23-31). Interestingly, we have recently reported a novel molecular vitamin D-derived mechanism that can also target early stages of the viral cycle via downregulating the expression of host cell receptors for viral attachment. This novel mechanism is responsible for impairing binding and entry of dengue virus, thus, restricting in vitro infection (22) and likely, further dissemination to other primary host cells.

SARS-CoV-2 can target both upper and lower epithelial lung cells and gain access to, via anchoring of its spike (S) protein to angiotensin-converting enzyme 2 (ACE2) receptor (32-36). This receptor is an important enzyme for the regulation of the Renin-Angiotensin System (RAS) which regulates blood pressure and vascular balance. Notably, ACE2 is highly expressed in patients with hypertension, diabetes mellitus, coronary heart diseases, and cerebrovascular disease, which could explain the higher risk of severe and fatal COVID-19 within these patients $(37,38)$. In fact, recently it has been demonstrated that SARS-CoV-2 can also bind and infect central nervous system cells through targeting the ACE2 receptor, implicating participation of this neurotropic mechanism into the disease severity and mortality (39). 
As concerning inferences may arise from all these observations, it is important to note that ACE2 receptor has been broadly known to be downregulated by vitamin $\mathrm{D}$ activity (40). Mechanistically, vitamin D works as a potent negative endocrine regulator of the RAS via the canonical vitamin $\mathrm{D}$ receptor pathway which can suppress RAS and downregulates the expression of ACE2 both in vitro and in vivo $(37,41)$. Indeed, it has been documented that vitamin D-derived suppression of RAS can be elicited via vitamin D inhibition of CREB (cAMP response element-binding protein), a transcription factor key for the renin gene regulation (42). Moreover, these experimental observations have been corroborated by mounting clinical and epidemiologic evidence, where decreased serum levels of vitamin D have been correlated with increased activity of RAS, higher plasma renin activity, and high blood pressure levels (43-46). For instance, improved vitamin D serum concentrations due to oral supplementation within hypertensive patients that were previously vitamin $\mathrm{D}$ insufficient, were associated with improvement in the control of blood pressure (47).

In light of these observations, we anticipate in this comment that the regulating effects of vitamin $\mathrm{D}$ on the renin-angiotensin system, specifically, on ACE2 receptor downregulation could contribute with restriction of SARS-CoV-2, similarly to what we have reported with dengue virus (22). Accordingly, an increasing number of studies are postulating blockade of this receptor as a likely therapeutic strategy for COVID-19 (2, 48-50). Furthermore, besides infection, severity of COVID19 is strongly associated with altered and prolonged proinflammatory responses in the lung, that ultimately lead to abnormal respiratory events and further organ failure (3). In line with literature, our experimental model has shown that beyond the vitamin $\mathrm{D}$-derived downregulation of relevant receptors for viral attachment, this hormone can also contribute with fine tuning of the altered pro-inflammatory responses induced by the virus $(22,51)$. In fact, others have reported that vitamin $\mathrm{D}$-derived alleviation of pulmonary damage, caused by inflammation, in a model of acute lung injury, and respiratory distress was related to modulation of several members of RAS, including ACE2 receptor $(37,40,41,52)$.

In line with findings from other reports (10), our observations that vitamin $\mathrm{D}$-derived antiviral mechanisms can restrict viral infection and attenuate the pro-inflammatory response (22) have been corroborated ex vivo in two different vitamin D

\section{REFERENCES}

1. Mahase E. Coronavirus covid-19 has killed more people than SARS MERS combined, despite lower case fatality rate. BMJ. (2020) 368:m641. doi: 10.1136/bmj.m641

2. Guo Y-R, Cao Q-D, Hong Z-S, Tan Y-Y, Chen S-D, Jin H-J, et al. The origin, transmission and clinical therapies on coronavirus disease 2019 (COVID-19) outbreak - an update on the status. Mil Med Res. (2020) 7:11. doi: 10.1186/s40779-020-00240-0

3. Rothan HA, Byrareddy SN. The epidemiology pathogenesis of coronavirus disease (COVID-19) outbreak. J Autoimmun. (2020) 109:102433. doi: 10.1016/j.jaut.2020.102433 supplementation exploratory studies. We demonstrated that a daily oral supplement of $4000 \mathrm{IU}$ of vitamin D during 10 days represented an adequate dose to enhance dengue virus control and reduce the cytokine response, in vitro, suggesting that vitamin $\mathrm{D}$ status can, in fact, restrict the viral assault $(53,54)$. Accordingly, several studies have highlighted the beneficial role of vitamin D sufficiency levels and supplementation for viral respiratory infections (55-57). Indeed, outbreaks and higher incidence of respiratory viruses such as influenza and coronavirus are common beyond subtropical areas with low sunlight exposure levels and prevalence of vitamin D deficiency/insufficiency such as Europe and Northern United States, which have been highly affected by COVID-19 $(10,11,58)$.

While several drugs targeting the ACE2-dependet entry pathway for SARS-CoV-2 still await for validation and assessment of their side effects $(6,7,49,59)$, at least three clinical trials aimed to elucidate the protective role of vitamin $\mathrm{D}$ role on COVID-19 disease severity are currently progressing in Spain, France and United States (60-62). Moreover, a mounting number of observations worldwide, are consistently suggesting the preventive and prophylactic features vitamin $\mathrm{D}$ status for COVID-19 mortality (63-66).

Our hypothesis provides a call for research pathways to unravel the role of vitamin D on the pathogenesis of COVID19, but beyond that, it also opens a hope window for a more immediate, accessible, natural, and cost-effective strategy to prevent, treat and ameliorate propagation of SARS-CoV-2. In summary, we postulate that conventional oral vitamin $\mathrm{D}$ supplementation can be a readily strategy to aim: (i) restriction of SARS-CoV-2 infection via downregulation of ACE2 receptor, and (ii) attenuation of disease severity by down-tuning the pulmonary pro-inflammatory response or cytokine storm that fuels COVID-19 severity. Therefore, verifying its beneficial role by means of epidemiologic, clinical and experimental in vivo and in vitro evidence may turn Vitamin D into a new "at hand tool" to protect vulnerable populations and mitigate the impact of the current pandemic events, especially in countries with reduced capability of their public health systems.

\section{AUTHOR CONTRIBUTIONS}

All authors listed have made a substantial, direct and intellectual contribution to the work, and approved it for publication.
4. Cui Y, Zhang Z-F, Froines J, Zhao J, Wang H, Yu S-Z, et al. Air pollution and case fatality of SARS in the People's Republic of China: an ecologic study. Environ Heal. (2003) 2:15. doi: 10.1186/1476069X-2-15

5. WHO. Coronavirus Disease 2019 (2019). Available online at: https://www. who.int/emergencies/diseases/novel-coronavirus-2019 (accessed March 21, 2020).

6. Li G, De Clercq E. Therapeutic options for the 2019 novel coronavirus (2019-nCoV). Nat. Rev. Drug Discov. (2020) 19:149-50. doi: 10.1038/d41573-020-00016-0

7. Ahmed SF, Quadeer AA, McKay MR. Preliminary identification of potential vaccine targets for the COVID-19 coronavirus (SARS-CoV-2) based on 
SARS-CoV immunological studies. Viruses. (2020) 12:254. doi: 10.3390/v120 30254

8. Grant WB, Lahore H, McDonnell SL, Baggerly CA, French CB, Aliano JL, et al. Vitamin D supplementation could prevent and treat influenza, coronavirus. Pneumonia Infect. (2020) 12:988. doi: 10.20944/preprints202003.0235.v1

9. Wilder-Smith A, Freedman DO. Isolation, quarantine, social distancing community containment: pivotal role for old-style public health measures in the novel coronavirus (2019-nCoV) outbreak. J Travel Med. (2020) 27:taaa020. doi: $10.1093 / \mathrm{jtm} / \mathrm{taaa} 020$

10. Beard JA, Bearden A, Striker R. Vitamin D the anti-viral state. J Clin Virol. (2011) 50:194-200. doi: 10.1016/j.jcv.2010.12.006

11. Greiller CL, Martineau AR. Modulation of the immune response to respiratory viruses by vitamin D. Nutrients. (2015) 7:4240-70. doi: 10.3390/nu7064240

12. Schögler, Muster RJ, Kieninger E, Casaulta C, Tapparel C, Jung A, et al. Vitamin D represses rhinovirus replication in cystic fibrosis cells by inducing LL-37. Eur Respir J. (2015) 47:520-30. doi: 10.1183/13993003.00665-2015

13. Grant WB. Vitamin D supplementation could reduce the risk of type A influenza infection subsequent pneumonia. Pediatr Infect Dis J. (2010) 29:987. doi: 10.1097/INF.0b013e3181e50e10

14. Khare D, Godbole NM, Pawar SD, Mohan V, Pandey G, Gupta S, et al. Calcitriol [1, 25[OH]2 D3] pre- and post-treatment suppresses inflammatory response to influenza A (H1N1) infection in human lung A549 epithelial cells. Eur J Nutr. (2012) 52:1405-15. doi: 10.1007/s00394-012-0449-7

15. Sabetta JR, DePetrillo P, Cipriani RJ, Smardin J, Burns LA, Landry ML. Serum 25-hydroxyvitamin $\mathrm{d}$ and the incidence of acute viral respiratory tract infections in healthy adults. PLOS ONE. (2010) 5:e11088. doi: 10.1371/journal.pone.0011088

16. Maxwell CS, Carbone ET, Wood RJ. Better newborn vitamin D status lowers RSV-associated bronchiolitis in infants. Nutr Rev. (2012) 70:548-52. doi: 10.1111/j.1753-4887.2012.00517.x

17. Urashima M, Mezawa H, Noya M, Camargo CA. Effects of vitamin D supplements on influenza A illness during the 2009 H1N1 pandemic: a randomized controlled trial. Food Funct. (2014) 5:2365-70. doi: 10.1039/C4FO00371C

18. Loeb M, Dang AD, Thiem VD, Thanabalan V, Wang B, Nguyen NB, et al. Effect of Vitamin D supplementation to reduce respiratory infections in children and adolescents in Vietnam: a randomized controlled trial influenza other respi. Viruses. (2019) 13:176-83. doi: 10.1111/irv.12615

19. Urashima M, Segawa T, Okazaki M, Kurihara M, Wada Y, Ida H, et al. Randomized trial of Vitamin D supplementation to prevent seasonal influenza A in schoolchildren. Am J Clin Nutr. (2010) 91:1255-60. doi: 10.3945/ajcn.2009.29094

20. Campbell GR, Spector SA. Vitamin D inhibits human immunodeficiency virus type 1 and Mycobacterium tuberculosis infection in macrophages through the induction of autophagy. PLoS Pathog. (2012) 8:e1002689. doi: 10.1371/journal.ppat.1002689

21. Gal-Tanamy M, Bachmetov L, Ravid A, Koren R, Erman A, Tur-Kaspa R, et al. Vitamin D: an innate antiviral agent suppressing hepatitis $\mathrm{C}$ virus in human hepatocytes. Hepatology. (2011) 54:1570-9. doi: 10.1002/hep. 24575

22. Arboleda Alzate JF, Rodenhuis-Zybert IA, Hernández JC, Smit JM, UrcuquiInchima S. Human macrophages differentiated in the presence of vitamin D3 restrict dengue virus infection and innate responses by downregulating mannose receptor expression. PLoS Negl Trop Dis. (2017) 11:e0005904. doi: 10.1371/journal.pntd.0005904

23. Hewison M. Vitamin D and innate immunity. Curr Opin Investig Drugs. (2008) 9:485-90.

24. Bergman P, Walter-Jallow L, Broliden K, Agerberth B, Söderlund J. The antimicrobial peptide LL-37 inhibits HIV-1 replication. Curr HIV Res. (2007) 5:410-5. doi: 10.2174/157016207781023947

25. Lee C-J, Buznyk O, Kuffova L, Rajendran V, Forrester VJ, Phopase J, et al. Cathelicidin LL-37 and HSV-1 corneal infection: peptide versus gene therapy. Transl Vis Sci Technol. (2014) 3:4. doi: 10.1167/tvst.3.3.4

26. Tangpricha V, Judd SE, Ziegler TR, Hao L, Alvarez JA, Fitzpatrick AM, et al. LL-37 concentrations and the relationship to vitamin D, immune status, and inflammation in HIV-infected children and young adults. AIDS Res Hum Retroviruses. (2014) 30:670-6. doi: 10.1089/aid.2013.0279
27. Zhao Y, Yu B, Mao X, He J, Huang Z, Zheng P, et al. Effect of 25hydroxyvitamin D3 on rotavirus replication and gene expressions of RIG-I signalling molecule in porcine rotavirus-infected IPEC-J2 cells. Arch Anim Nutr. (2015) 69:227-35. doi: 10.1080/1745039X.2015.1034522

28. Castellani ML, Shaik-Dasthagirisaheb YB, Tripodi D, Anogeianaki A, Felaco $\mathrm{P}$, Toniato $\mathrm{E}$, et al. Interrelationship between vitamins and cytokines in immunity. J Biol Regul Homeost Agents. (2010) 24:385-90.

29. Sacco RE, Nonnecke BJ, Palmer VM, Waters WR, Lippolis JD, Reinhardt TA. Differential expression of cytokines in response to respiratory syncytial virus infection of calves with high or low circulating 25-hydroxyvitamin D3. PLoS ONE. (2012) 7:e33074. doi: 10.1371/journal.pone.0033074

30. Fitch N, Becker AB, HayGlass KT. Vitamin D [1,25(OH)2D3] differentially regulates human innate cytokine responses to bacterial versus viral pattern recognition receptor stimuli. J Immunol. (2016) 196:2965-72. doi: 10.4049/jimmunol.1500460

31. Staeva-Vieira TP, Freedman LP. 1,25-dihydroxyvitamin D3 inhibits IFNgamma IL-4 levels during in vitro polarization of primary murine CD4+ T cells. J Immunol. (2002) 168:1181-9. doi: 10.4049/jimmunol.168.3.1181

32. Ge X-Y, Li J-L, Yang X-L, Chmura AA, Zhu G, Epstein JH, et al. Isolation and characterization of a bat SARS-like coronavirus that uses the ACE2 receptor. Nature. (2013) 503:535-8. doi: 10.1038/nature12711

33. Prabakaran P, Xiao X, Dimitrov DS. A model of the ACE2 structure and function as a SARS-CoV receptor. Biochem Biophys Res Commun. (2004) 314:235-41. doi: 10.1016/j.bbrc.2003.12.081

34. Dimitrov DS. The secret life of ACE2 as a receptor for the SARS virus. Cell. (2003) 115:652-3. doi: 10.1016/S0092-8674(03)00976-0

35. Chen Y, Guo Y, Pan Y, Zhao ZJ. Structure analysis of the receptor binding of 2019-nCoV. Biochem Biophys Res Commun. (2020) 525:135-40. doi: 10.1016/j.bbrc.2020.02.071

36. Lu R, Zhao X, Li J, Niu P, Yang B, Wu H, et al. Genomic characterisation and epidemiology of 2019 novel coronavirus: implications for virus origins and receptor binding. Lancet. (2020) 395:565-74. doi: 10.1016/S0140-6736(20)30251-8

37. Ajabshir S, Asif A, Nayer A. The effects of vitamin D on the renin-angiotensin system. J Nephropathol. (2014) 3:41-3. doi: 10.12860/jnp.2014.09

38. Fang L, Karakiulakis G, Roth M. Are patients with hypertension and diabetes mellitus at increased risk for COVID-19 infection? Lancet Respir Med. (2020) 8:e21. doi: 10.1016/S2213-2600(20)30116-8

39. Baig AM, Khaleeq A, Ali U, Syeda H. Evidence of the COVID-19 virus targeting the CNS: tissue distribution, host-virus interaction, and proposed neurotropic mechanisms. ACS Chem Neurosci. (2020) 11:995-8. doi: 10.1021/acschemneuro.0c00122

40. Xu J, Yang J, Chen J, Luo Q, Zhang Q, Zhang H. Vitamin D alleviates lipopolysaccharide-induced acute lung injury via regulation of the renin-angiotensin system. Mol Med Rep. (2017) 16:7432-8. doi: $10.3892 / \mathrm{mmr} .2017 .7546$

41. Li YC. Vitamin D regulation of the renin-angiotensin system. J Cell Biochem. (2003) 88:327-31. doi: 10.1002/jcb.10343

42. Yuan W, Pan W, Kong J, Zheng W, Szeto FL, Wong KE, et al. 1,25dihydroxyvitamin D3 suppresses renin gene transcription by blocking the activity of the cyclic AMP response element in the renin gene promoter. J Biol Chem. (2007) 282:29821-30. doi: 10.1074/jbc.M705495200

43. Scragg R, Sowers M, Bell C. Serum 25-hydroxyvitamin D, ethnicity, blood pressure in the third national health nutrition examination survey. $J$ Hypertens. (2007) 20:713-9. doi: 10.1016/j.amjhyper.2007.01.017

44. Hintzpeter B, Mensink GBM, Thierfelder W, Müller MJ, Scheidt-Nave C. Vitamin D status health correlates among German adults. J Clin Nutr. (2008) 62:1079-89. doi: 10.1038/sj.ejcn.1602825

45. Forman JP, Williams JS, Fisher NDL. Plasma 25-Hydroxyvitamin D and regulation of the renin-angiotensin system in humans. Hypertension. (2010) 55:1283-8. doi: 10.1161/HYPERTENSIONAHA.109.148619

46. Resnick LM, Müller FB, Laragh JH. Calcium-regulating hormones in essential hypertension. Ann Intern Med. (1986) 105:649. doi: 10.7326/0003-4819-105-5-649

47. Mirhosseini N, Vatanparast H, Kimball S. The association between serum $25(\mathrm{OH}) \mathrm{D}$ status and blood pressure in participants of a communitybased program taking Vitamin D supplements. Nutrients. (2017) 9:1244. doi: $10.3390 /$ nu9111244 
48. Diaz JH. Hypothesis: angiotensin-converting enzyme inhibitors angiotensin receptor blockers may increase the risk of severe COVID-19. J Travel Med. (2020) 27:taaa041. doi: 10.1093/jtm/taaa041

49. Meili S, Jianmin Y, Yuping S, Guohai S. Inhibitors of RAS might be a good choice for the therapy of COVID-19 pneumonia Chinese. J Tuberc Respir Dis. (2020) 43:E014. doi: 10.3760/cma.j.issn.1001-0939.2020.0014

50. Batlle D, Wysocki J, Satchell K. Soluble angiotensin-converting enzyme 2: a potential approach for coronavirus infection therapy? Clin Sci. (2020) 134:543-5. doi: 10.1042/CS20200163

51. Hewison M. Vitamin D and immune function: an overview. Proc Nutr Soc. (2012) 71:50-61. doi: 10.1017/S0029665111001650

52. Agarwal R. Are vitamin D receptor agonists like angiotensin-converting enzyme inhibitors without side effects?. Kidney Int. (2010) 77:943-5. doi: $10.1038 / \mathrm{ki} .2010 .77$

53. Giraldo DM, Cardona A, Urcuqui-Inchima S. High-dose of vitamin D supplement is associated with reduced susceptibility of monocyte-derived macrophages to dengue virus infection and pro-inflammatory cytokine production: an exploratory study. Clin Chim Acta. (2018) 478:140-51. doi: 10.1016/j.cca.2017.12.044

54. Martínez-Moreno J, Hernandez JC, Urcuqui-Inchima S. Effect of high doses of vitamin D supplementation on dengue virus replication, Toll-like receptor expression, and cytokine profiles on dendritic cells. Mol Cell Biochem. (2019) 464:169-80. doi: 10.1007/s11010-019-03658-w

55. Berry DJ, Hesketh K, Power C, Hyppönen E. Vitamin D status has a linear association with seasonal infections lung function in British adults. Br J Nutr. (2011) 106:1433-40. doi: 10.1017/S0007114511001991

56. Laaksi I, Ruohola J, Mattila V, Auvinen A, Ylikomi T, Pihlajamäki H, et al. Vitamin D supplementation for the prevention of acute respiratory tract infection: a randomized, double-blinded trial among young finnish men. $J$ Infect Dis. (2010) 202:809-14. doi: 10.1086/654881

57. Moan J, Dahlback A, Ma L, Juzeniene A. Influenza, solar radiation and vitamin D. Dermatoendocrinol. (2009) 1:307-9. doi: 10.4161/derm.1.6.11357

58. Davidson BL, Alansari K. Vitamin D deficiency can impair respiratory health. Respirology. (2018) 23:554-5. doi: 10.1111/resp.13290

59. Cascella M, Rajnik M, Cuomo A, Dulebohn SC, Di Napoli R. Features, Evaluation and Treatment Coronavirus (COVID-19). Trasure Island, FL: StatPearls (2020).
60. The LEAD COVID-19 Trial: Low-risk, Early Aspirin and Vitamin D to Reduce COVID-19 Hospitalizations - Full Text View - http://clinicaltrials.gov (2020). Available online at: https://clinicaltrials.gov/ct2/show/NCT04363840 (accessed May 13, 2020).

61. COvid-19 and Vitamin D Supplementation: A Multicenter Randomized Controlled Trial of High Dose Versus Standard Dose Vitamin D3 in HighRisk COVID-19 Patients (CoVitTrial) - Full Text View - http://clinicaltrials. gov. Available online at: https://clinicaltrials.gov/ct2/show/NCT04344041 (accessed May 13, 2020).

62. Vitamin D on Prevention and Treatment of COVID-19 - Full Text View - ClinicalTrials.gov. Available online at: https://clinicaltrials.gov/ct2/show/ NCT04334005 (accessed May 13, 2020).

63. Alipio M. Vitamin D supplementation could possibly improve clinical outcomes of patients infected with coronavirus-2019 (COVID-2019). SSRN Electron J. (2020). doi: 10.2139/ssrn.3571484. [Epub ahead of print].

64. Raharusun P, Priambada S, Budiarti C, Agung E, Budi C. Patterns of COVID19 mortality Vitamin D: an Indonesian study. SSRN Electron J. (2020). doi: 10.2139/ssrn.3585561. [Epub ahead of print].

65. Glicio EJ. Vitamin D Level of Mild and Severe Elderly Cases of COVID-19: A Preliminary Report. (2020). Available online at: https://papers.ssrn.com/ sol3/papers.cfm?abstract_id=3593258\#.XrE0oF1wSjU.twitter (accessed May 13, 2020).

66. Ilie PC, Stefanescu S, Smith L. The role of vitamin D in the prevention of coronavirus disease 2019 infection and mortality. Aging Clin Exp Res. (2020). doi: 10.1007/s40520-020-01570-8. [Epub ahead of print].

Conflict of Interest: The authors declare that the research was conducted in the absence of any commercial or financial relationships that could be construed as a potential conflict of interest.

Copyright (c) 2020 Arboleda and Urcuqui-Inchima. This is an open-access article distributed under the terms of the Creative Commons Attribution License (CC BY). The use, distribution or reproduction in other forums is permitted, provided the original author(s) and the copyright owner(s) are credited and that the original publication in this journal is cited, in accordance with accepted academic practice. No use, distribution or reproduction is permitted which does not comply with these terms. 